\title{
Røyking gir økt risiko for seneskader i skulderen
}

\section{Senedegenerasjon og omfang av programmert celledød forsterkes av røyking.}

Forekomsten av skuldersmerter øker med alderen og er relatert til aldringsprosesser i senemansjetten som omgir skulderen. Disse påvirkes av livsstil, genetiske faktorer og skader. Tilhelingspotensialet etter sutur av senerifter i skulderen påvirkes av riftens størrelse, skadens varighet, pasientens alder og livsstil samt sekundære forandringer i tilhørende muskulatur.

Vi ønsket å kartlegge omfanget av senedegenerasjon samt ledsagende endringer i muskulaturen hos pasienter med deltykkelseskader og fulltykkelseskader i senemansjetten. Vi så spesielt etter en sammenheng mellom omfanget av programmert celledød, degenerative forandringer, celleproliferasjon og røyking.

Senevevs- og muskelvevsbiopsier ble høstet i forbindelse med artroskopisk sutur av senerifter og sammenliknet med hverandre og med vevsbiopsier fra friske seneman- sjetter. Analysene gjorde vi ved University of British Columbia, Vancouver, Canada.

Økt omfang av programmert celledød forekom allerede før etablering av fulltykkelseskader og affiserte senemansjetten generelt. Større skadeomfang var ledsaget av redusert muskelregenereringsaktivitet. Røykerne var yngre enn de andre pasientene, og deres senevev var mer preget av degenerasjon og celledød. Hvorvidt økt programmert celledød er en årsak eller en konsekvens av degenerasjonsprosessen i senemansjetten, er uklart.

Avhandlingen indikerer at forsterket celledød er en faktor ved degenerering av skulderens senemansjett, og at røyking svekker senevevet samt reduserer tilhelingspotensialet.

\section{Kirsten Lundgreen}

kiraten.lundgreen@lds.no

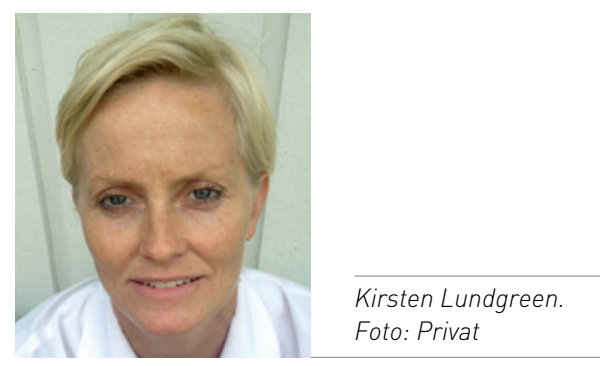

Disputas

Kirsten Lundgreen disputerte for ph.d.-graden ved Universitetet i Oslo 4.4. 2014. Avhandlingens tittel er The role of apoptosis in rotator cuff tendinopathy

\section{Genekspresjon i ovariale karsinomer - betydning for prognose og overlevelse}

\section{De gener som uttrykkes mest ulikt i forskjellige typer eggstokkreft er iden- tifisert. Noen av disse genene er assosiert med prognose og overlevelse.}

Ovariecancer er den fjerde hyppigste årsak til kreftdød hos kvinner i Norge. De aller fleste tilfeller oppdages i sene stadier, der færre enn $30 \%$ er i live etter fem år.

Ovariale karsinomer utgjør mer enn $90 \%$ av tilfellene av ovariecancer og består av flere undergrupper som atskiller seg genetisk, biologisk og klinisk. Likevel behandles pasientene med ulik type ovariale karsinomer i dag stort sett likt og lite målrettet. Økt innsikt $\mathrm{i}$ karsinogenesen for de ulike subgruppene er derfor grunnleggende for å identifisere nye subgruppespesifikke terapeutiske angrepspunkter - for deretter å kunne utvikle mer skreddersydde og effektive behandlingsstrategier.

I mitt doktorgradsarbeid er ekspresjon av alle kjente gener i form av mRNA og miRNA i ulike typer ovariale karsinomer og normalt ovarialt overflateepitel undersøkt ved global genekspresjonsprofilering og RTqPCR-analyser. Mens det fra mRNA produseres protein, kan miRNA ved å interagere med mRNA bidra til å styre proteinproduksjonen. Mange differensielt uttrykte mRNA og miRNA mellom de ulike gruppene ble identifisert, hvorav flere også var assosiert med prognostiske faktorer samt totaloverlevelse og progredieringsfri overlevelse. Molekylære signalveier og mRNA-miRNAinteraksjoner ble også kartlagt.

Mange av de identifiserte mRNA og miRNA deltar med stor sannsynlighet i utviklingen av ulike typer ovariale karsinomer og representerer potensielle angrepspunkter for fremtidig målrettet behandling av pasienter med ovariecancer.

Bente Vilming Elgaaen benelg@ous-hf.no

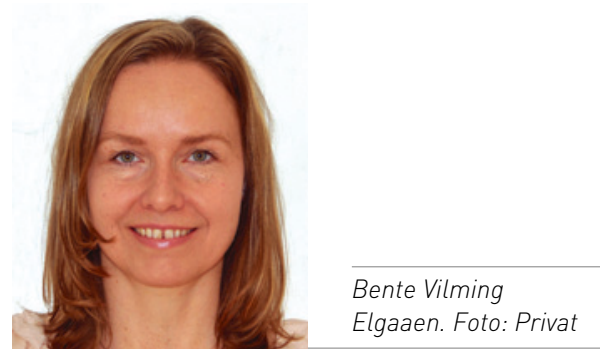

Disputas

Bente Vilming Elgaaen disputerte for ph.d.graden ved Universitetet i Oslo 20.3. 2014. Tittelen på avhandlingen er Gene expression in ovarian carcinoma and correlation with prognostic factors and survival - a study of mRNA and miRNA profiling and differentiality. 